\title{
PENGARUH PEMBINAAN TERHADAP MOTIVASI KERJA DAN PRODUKTIVITAS KERJA PEGAWAI NEGERI SIPIL (Studi: Pemerintah Daerah Kabupaten Serdang Bedagai)
}

\author{
THE EFFECT ON MOTIVATION DEVELOPMENT WORK AND WORK \\ PRODUCTIVITY OF CIVIL SERVANTS \\ (Study: Local Government Serdang Bedagai)
}

\author{
Herman Ya'aro Harefa ${ }^{1}$ dan Tiurlan Sinambela ${ }^{2}$ \\ Badan Penelitian dan Pengembangan Kementerian Dalam Negeri \\ Jalan Kramat Raya No.132, Senen - Jakarta Pusat \\ e-mail: h.harefa@yahoo.com ${ }^{1}$ dan dickymarpaung@rocketmail.com ${ }^{2}$ \\ Diterima: 4 Juli 2012; direvisi: 5 Agustus 2012; disetujui: 10 Agustus 2012
}

\begin{abstract}
Abstrak
Tujuan penelitian ini adalah untuk mengetahui pengaruh pembinaan terhadap produktivitas kerja melalui motivasi kerja pada organisasi pemerintahan daerah. Lokasi penelitian adalah pemerintah daerah Kabupaten Serdang Bedagai. Penelitian ini menggunakan teknik analisis Structural Equation Model (SEM), dengan responden sebanyak 139 orang yang penarikan sampelnya menggunakan Simple Random Sampling. Hasil analisis statistik menunjukkan bahwa pembinaan tidak berpengaruh signifikan terhadap produktivitas kerja, pembinaan berpengaruh signifikan terhadap motivasi kerja, motivasi kerja berpengaruh signifikan terhadap produktivitas kerja, dan pembinaan melalui motivasi kerja berpengaruh signifikan terhadap produktivitas kerja.
\end{abstract}

Kata kunci: PNS, motivasi kerja, produktivitas pegawai, pemerintah.

\begin{abstract}
The purpose of this study was to determine the effect of coaching on work productivity through motivation in organizational governance. What research is Serdang Bedagai local government. This study uses analytical techniques Structural Equation Model (SEM), with 139 respondents who recall sampled using Simple Random Sampling. The results of statistical analysis showed that no significant effect on guidance through, guidance through significant effect on work motivation, work motivation significant effect on workplace productivity, motivation and guidance through a significant effect on labor productivity.

Keywords: civil servants, work motivation, employee productivity, government.
\end{abstract}

\section{PENDAHULUAN}

Implementasi otonomi daerah sebagai wujud azas desentralisasi yang saat ini dilakukan di Indonesia, telah memberikan kewenangan penuh kepada daerah untuk mengelola dan membangun daerahnya dalam rangka meningkatkan kesejahteraan masyarakat. Daerah sebagai ujung tombak pembangunan nasional, memegang peranan penting dan strategis. Dikatakan strategis karena sebagai bagian dari suatu sistem besar pemerintah, daerah memainkan peranan penting dalam pembangunan bangsa, yaitu sebagai katalisator pembangunan nasional yang dapat berfungsi sebagai pelayan terdekat terhadap masyarakat di daerah.

Dalam melaksanakan fungsi pelayanan tersebut, pemerintah daerah sebagai sebuah organisasi harus mampu membangun kredibilitas dan kinerjanya secara baik sesuai harapan masyarakat. Kredibilitas dan kinerja itu ditentukan oleh seberapa baik produktivitas kerja dalam melaksanakan tugas, sesuai dengan wewenang dan tanggung jawab masingmasing dalam mencapai tujuan otonomi daerah.
Namun, produktivitas para pegawai itu sendiri tidak hanya dipengaruhi oleh pelaksanaan tugas dan pekerjaannya, tetapi ditentukan juga oleh antara lain pembinaan dan motivasi kerja yang berjalan selama ini di lingkungan pemerintah daerah.

Pembinaan dipandang sebagai salah satu prediktor penting yang mempengaruhi produktivitas kerja. Kesuksesan organisasi, khususnya pemerintah daerah dalam mencapai tujuan dan sasarannya tergantung pada pembinaan yang dilakukan atasan. Disamping itu, peran pembinaan atasan dalam mengarahkan dan memberdayakan pegawai akan mempengaruhi produktivitas kerja. Pembinaan oleh atasan memiliki dampak signifikan terhadap sikap, perilaku dan produktivitas kerja.

Sebagai sebuah organisasi, pemerintah daerah Kabupaten Serdang Bedagai yang merupakan salah satu daerah otonomi baru dan dibentuk berdasarkan Undang-Undang Nomor 36 Tahun 2003 dihadapkan pada situasi kompetisi dan persaingan global yang tinggi serta senantiasa menghadapi lingkungan yang selalu berubah. Menghadapi situasi itu, pemerintah daerah Kabupaten Serdang Bedagai harus senantiasa 
melakukan transformasi agar dapat menjadi daerah otonom yang mandiri dan berdaya saing tinggi.

Melihat kondisi obyektif bahwa produktivitas kerja di lingkungan pemerintah daerah Kabupaten Serdang Bedagai, saat ini menunjukkan peningkatan dengan adanya transformasi di segala bidang pembangunan, maka penelitian ini bertujuan untuk mengetahui dan menganalisis faktor-faktor apa saja yang mempengaruhi produktivitas kerja, khususnya pembinaan, terhadap motivasi kerja dan produktivitas kerja yang pada akhirnya akan berdampak pada kinerja pemerintah daerah Kabupaten Serdang Bedagai.

Pertanyaan penelitian ini adalah:

1. Apakah pembinaan berpengaruh signifikan terhadap produktivitas kerja di pemerintah daerah Kabupaten Serdang Bedagai?

2. Apakah pembinaan berpengaruh signifikan terhadap motivasi kerja di pemerintah daerah Kabupaten Serdang Bedagai?

3. Apakah motivasi kerja berpengaruh signifikan terhadap produktivitas kerja di pemerintah daerah Kabupaten Serdang Bedagai?

4. Apakah pembinaan melalui motivasi kerja berpengaruh signifikan terhadap produktivitas kerja di pemerintah daerah Kabupaten Serdang Bedagai?

Thoha (1993) mengatakan bahwa pembinaan merupakan suatu tindakan, proses, hasil, atau pernyataan menjadi lebih baik. Pembinaan menunjukkan adanya kemajuan, peningkatan, perubahan, evolusi atas berbagai kemungkinan, berkembang, atau peningkatan atas sesuatu. Ditambahkan Thoha, bahwa semakin baik pembinaan yang dilakukan, maka akan semakin meningkatkan produktivitas kerja secara relatif, artinya semakin baik pembinaan yang dilakukan unsur pimpinan terhadap pegawai, maka akan semakin meningkat pula produktivitas kerjanya

Adapun, menurut Handoko (2001), pembinaan (coaching) merupakan upaya berharga untuk membantu orang lain mencapai kinerja puncak. Sementara Minor (2003) mengatakan bahwa "membina adalah proses mengarahkan yang dilakukan oleh seorang manajer untuk melatih dan memberikan orientasi kepada seorang karyawan tentang realitas di tempat kerja dan membantunya mengatasi hambatan dalam mencapai prestasi optimum". Hal dimaksud erat kaitannya dengan kata membina yang diartikan sebagai "membimbing (counselling)", yaitu proses pemberian dukungan oleh pembina untuk membantu seorang pegawai mengatasi masalah akibat perubahan organisasi yang berdampak pada prestasi kerja. Secara implisit, pembinaan dilakukan secara terencana, sistematis dan terintegrasi.

Sejalan dengan perubahan dalam organisasi, pembinaan berkelanjutan merupakan suatu cara untuk mendukung pengembangan organisasi. Ini berarti, pembinaan merupakan proses berkelanjutan dan harus terus menerus memberi berbagai arahan dan dukungan. Dengan demikian, yang disebut pembina adalah seorang pimpinan dan motivator bagi orang lain, di mana tugasnya adalah untuk membantu orang lain agar bekerja lebih baik, sehingga keberhasilan memfasilitasi tergantung pada keterampilan seorang pimpinan menangani situasi tertentu, yakni terkait dengan tugas, motivasi, dan keyakinan diri.

Selanjutnya, Rumanti (2002) mengatakan bahwa etika profesi sangat penting terutama dalam rangka pembinaan pegawai, untuk meningkatkan mutu serta mewujudkan pribadi yang jujur, bersih, berwibawa, pegawai yang semakin ikut memiliki organisasinya, rasa ikut memiliki besar. Etika profesi menjiwai pegawai dalam menjalankan tugasnya, sehingga mampu menyelesaikan dengan seksama, etos kerja tinggi dan penuh tanggung jawab, sehingga memperoleh hasil yang memuaskan.

Secara operasional, pembinaan adalah upaya yang dilakukan oleh masing-masing pimpinan SKPD di lingkungan pemerintah daerah Kabupaten Serdang Bedagai untuk memperbaiki kemampuan kerja para pegawai serta membantu para pegawai dalam memahami suatu pengetahuan praktis dan menerapkannya agar dapat meningkatkan ketrampilan, kecakapan dan sikap yang diperlukan oleh organisasi dalam mencapai tujuan, yang diukur berdasarkan indikator: disiplin kerja, karier, dan etika profesi.

Siagian (2004) menyatakan bahwa manusia dalam melakukan suatu kegiatan, dipengaruhi oleh daya dorong yang timbul dalam dirinya yang disebut motif internal, dan dapat dipengaruhi oleh daya dorong yang ditimbulkan di mana manusia itu berada dan disebut motif eksternal. Sedangkan menurut Robbins (1993) bahwa "terdapat tiga kata kunci dalam motivasi, yaitu: efford, organization, dan need".

Menurut As'ad (2001), motivasi yang berasal dari kata motive seringkali diartikan dengan istilah dorongan, di mana dorongan atau tenaga tersebut merupakan gerak jiwa dan jasmani untuk berbuat, sehingga motif tersebut merupakan driving force yang menggerakkan manusia untuk bertingkah laku, dan di dalam perbuatannya itu mempunyai tujuan tertentu.

Ditambahkan oleh As'ad bahwa motivasi seorang pegawai disebabkan adanya rangsanganrangsangan, di antaranya: 1) gaji yang mencukupi, terpenuhi kebutuhan hidupnya, dana sakit yang tersedia, bonus, dana pensiun; 2) lingkungan dan tempat kerja yang baik; 3) kesempatan untuk dapat mengambil keputusan dan menentukan kebijakan sendiri; 4) tantangan pekerjaan; keistimewaan, kedudukan dan gengsi pribadi; 5) perasaan seseorang anggota organisasi mau disejajarkan dirinya atau sikap simpatik rekan dan pimpinan; dan 6) jaminan masa dinas dan jabatan, rumah dan kendaraan.

Menurut Simanjuntak (2000), motivasi seseorang dipengaruhi oleh banyak faktor yang dapat dikelompokkan dalam tiga golongan, yaitu: 1) latar belakang; 2) sikap pribadi; dan 3) harapan, keinginan dan ambisi. Ketiga hal inilah yang harus diperhatikan oleh pemimpin untuk menumbuhkan motivasi 
bawahannya agar terdorong melakukan pekerjaan yang produktif.

Secara operasional, motivasi kerja adalah suatu upaya dari organisasi dalam menggerakkan para pegawai untuk menimbulkan atau meningkatkan semangat dan kegairahan kerja pegawai guna mencapai hasil yang diharapkan bersama di lingkungan SKPD masing-masing. Adapun indikator dari motivasi kerja adalah dorongan, harapan, dan insentif.

Secara umum menurut Sinungan (2005), produktivitas diartikan sebagai hubungan hasil nyata maupun fisik (barang atau jasa) dengan masukan yang sebenarnya. Masukan sering dibatasi dengan masukan tenaga kerja, sedangkan keluaran diukur dalam satuan fisik bentuk dan nilai. Produktivitas juga diartikan sebagai perbandingan ukuran harga bagi masukan dan hasil. Perbedaan antara kumpulan jumlah pengeluaran dan masukan.

Silalahi (2000) mengungkapkan bahwa produktivitas tenaga kerja diukur berdasarkan kinerja. Kinerja tidak lain adalah tindak nilai perilaku seorang pegawai terhadap peranan (function), kegiatan (activities), dan tugas (tasks) yang dituntut oleh persyaratan jabatan (jobrequirements). Ketiga komponen pekerjaan ini harus dilihat dari segi prosedur dan perusahaan kerja. Jadi, kinerja merupakan resultante dari fungsi persyaratan jabatan dan prosedur/organisasi kerja. Jika persyaratan kerja yang eksak dilengkapi dengan prosedur dan organisasi kerja yang kurang mantap, maka kinerja akan terpengaruh, dan demikian sebaliknya.

Simanjuntak (2000) mengungkapkan bahwa ada lima faktor utama yang mempengaruhi produktivitas kerja, yakni: 1) pendidikan dan pelatihan; 2) penghasilan dan jaminan sosial; 3) kesempatan kerja; 4) manajemen; dan 5) kebijakan pemerintah. Produktivitas dikembangkan untuk mengatur besarnya kemampuan menghasilkan nilai tambah atas komponen masukan yang digunakan. Produktivitas mengutarakan cara pemanfaatan secara baik terhadap sumber-sumber dalam memproduksi barang-barang. Produktivitas yang meningkat berarti kinerja yang baik, akan menjadi feedback bagi usaha atau motivasi pekerja pada tahap berikutnya. Semakin besar kemampuan itu dibina, semakin efektif pemanfaatan sumberdaya yang digunakan, dan ini berarti akan dapat menekan besarnya biaya per unit.

Prinsip manajemen merupakan salah satu cara peningkatan produktivitas, yaitu dengan peningkatan efisiensi, dengan mengurangi kebocoran sumbersumber yang digunakan secara maksimal, termasuk barang modal, bahan-bahan mentah dan setengah jadi dan tenaga kerja sendiri. Penggunaan sumber-sumber termasuk dikendalikan secara berdayaguna dan tepatguna/

Secara operasional, produktivitas kerja adalah perbandingan antara keluaran dan masukan baik barang maupun jasa dengan harapan meningkatkan produktivitas kerja akan membawa pengaruh terhadap peningkatan kualitas kerja pegawai dan ini akan dapat dicapai apabila pegawai tersebut mempunyai sikap mental dan pandangan wawasan yang luas, bahwa kualitas hidup itu dapat dicapai hanya dengan cara bekerja yang efektif dan efisien, yang diukur berdasarkan indikator: efisiensi, masukan, dan keluaran.

Dari kajian literatur, ada beberapa penelitian terdahulu yang membahas mengenai variabel penelitian ini, yakni:

1. T. Rusdi Ayub (1992): meneliti hubungan efektivitas pelaksanaan peraturan disiplin PNS dengan usaha pembinaan pegawai dengan menggunakan path analysis. Hasilnya menunjukkan bahwa disiplin merupakan keharusan untuk melakukan pembinaan terhadap pegawai, sehingga dengan disiplin dan pembinaan dapat meningkatkan produktivitas kerja.

2. Tim Peneliti Badan Kepegawaian Negara (2004): meneliti pengaruh pembinaan terhadap perilaku PNS, dengan menggunakan regresi berganda dan pendekatan kualitatif guna menjelaskan analisis statistik. Hasilnya menunjukkan bahwa pembinaan hendaknya dilakukan secara terarah, komprehensif dan berkesinambungan agar memiliki dampak positif terhadap perilaku pegawai.

Perbedaan penelitian ini dengan penelitian terdahulu di atas adalah terutama pada teknik analisis yang digunakan, yakni Structural Equation Modelling (SEM), lokus penelitian pada organisasi pemerintah di daerah, dan fokus penelitian yang lebih spesifik.

Pembinaan secara empirik maupun pustaka mendukung pencapaian produktivitas kerja secara optimal dan mempengaruhi timbulnya motivasi kerja bagi individul didalam suatu organisasi pemerintah, khususnya di daerah. Selain itu, bahwa dalam pembinaan untuk menghasilkan sumberdaya manusia yang profesional dengan integritas dan kinerja tinggi, diperlukan motivasi kerja yang secara sistematis menuntun para pegawai untuk meningkatkan komitmen dan kinerjanya. Untuk lebih jelasnya, kerangka konseptual tersebut dapat dilihat dalam Gambar 1.

Berdasarkan hal tersebut, maka dirumuskan hipotesis sebagai berikut:

H_1 Pembinaan berpengaruh signifikan terhadap produktivitas kerja pemerintah daerah Kabupaten Serdang Bedagai.

H_2 Pembinaan berpengaruh signifikan terhadap motivasi kerja.

H_3 Motivasi kerja berpengaruh signifikan terhadap produktivitas kerja pemerintah daerah Kabupaten Serdang Bedagai.

H_4 Pembinaan melalui motivasi kerja berpengaruh signifikan terhadap produktivitas kerja pemerintah daerah Kabupaten Serdang Bedagai.

Penelitian ini bertujuan untuk memperoleh gambaran yang nyata tentang pengaruh pembinaan 


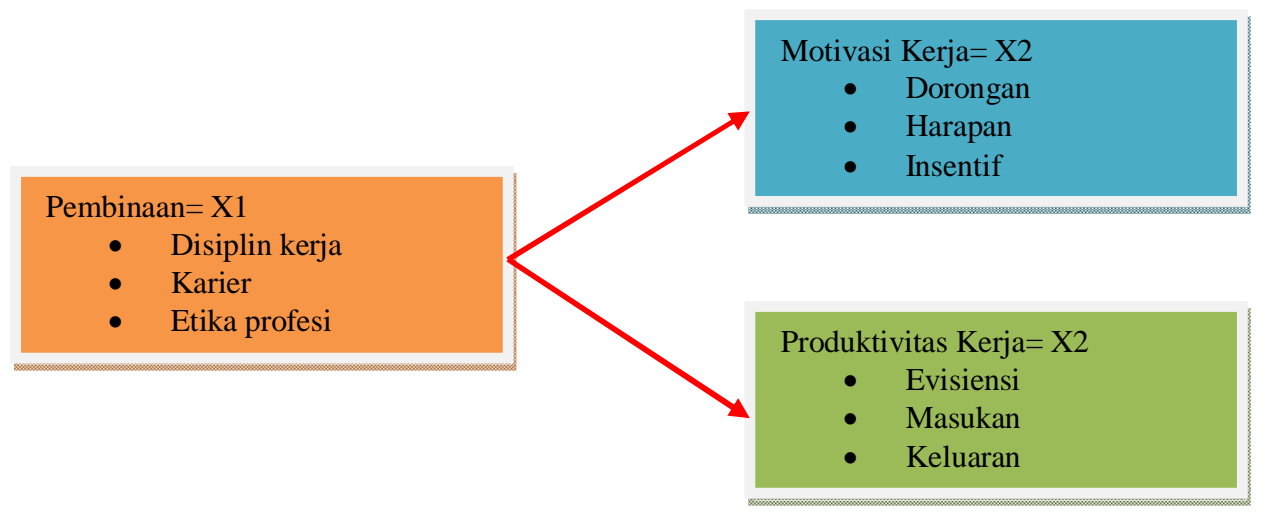

Gambar 1. Kerangka Konsep Hubungan Antar Variabel.

terhadap motivasi kerja dan produktivitas kerja di pemerintah daerah Kabupaten Serdang Bedagai. Hal ini sangat dibutuhkan, karena kabupaten ini termasuk daerah otonomi baru hasil pemekaran, yang membutuhkan percepatan pembangunan, dan hal itu dimulai dari kondisi sumberdaya manusia aparatur. Tempat penelitian adalah lingkungan pemerintah daerah Kabupaten Serdang Bedagai, pada periode waktu awal sampai akhir Juni 2012.

\section{METODE PENELITIAN}

Metode yang digunakan dalam penelitian ini adalah metode survei dengan pendekatan korelasional, dan pengumpulan data dilakukan dengan menyebarkan kuesioner kepada pegawai yang ada di lingkungan pemerintah daerah Kabupaten Serdang Bedagai. Teknik analisis yang digunakan adalah Structural Equation Modelling (SEM), yaitu untuk mengetahui pola hubungan antara variabel endogen dan eksogen. Dalam SEM, Solimun (2002) menyatakan bahwa ketepatan model dapat diperoleh dari hasil goodness of fit measurement model dengan bantuan software AMOS maupun Lisrell.

Populasi target adalah seluruh PNS di lingkungan pemerintah daerah Kabupaten Serdang Bedagai. Adapun populasi terjangkau yang menjadi target penelitian adalah PNS di lingkungan pemerintah daerah Kabupaten Serdang Bedagai dengan syarat: pendidikan minimal SMU; golongan minimal II/a; dan lama kerja di atas 2 tahun.

Teknik pengambilan sampel dilakukan dengan sampel acak sederhana (simple random sampling), karena populasi target homogen, yaitu PNS. Jumlah sampel menurut Solimun (2002) yang dipersyaratkan dalam SEM untuk penelitian adalah antara 100-200. Oleh karena itu, ditetapkan jumlah responden maksimal sebanyak 200, sehingga diharapkan dapat memperoleh hasil yang lebih baik (better fit).

\section{HASIL DAN PEMBAHASAN}

Kabupaten Serdang Bedagai dengan Ibukota Sei Rampah merupakan salah satu kabupaten dalam wilayah Provinsi Sumatera Utara yang dibentuk berdasarkan Undang-Undang Nomor 36 Tahun 2003 Pembentukan Kabupaten Samosir dan Kabupaten Serdang Bedagai, dengan batas-batas wilayah sebagai berikut: sebelah Utara berbatasan dengan Selat Malaka; sebelah Selatan berbatasan dengan Kabupaten Simalungun; sebelah Timur berbatasan dengan Kabupaten Batu Bara dan Kabupaten Simalungun; sebelah Barat berbatasan dengan Kabupaten Deli Serdang (kabupaten induk).

Luas wilayah Kabupaten Serdang Bedagai adalah $1.900,220 \mathrm{~km}^{2}$ yang terdiri dari 11 kecamatan dengan 6 kelurahan dan 237 desa. Menurut hasil pencacahan lengkap Sensus Penduduk 2011, penduduk Kabupaten Serdang Bedagai berjumlah 447.851 jiwa dengan komposisi pria 146.465 jiwa dan wanita 301.386 jiwa. Adapun jumlah PNS sebanyak 7.534 orang dengan komposisi jenis kelamin, yakni laki-laki sebanyak $3.033 \quad(40,26$ persen $)$ dan perempuan sebanyak 4.501 (59,74 persen). Untuk lebih jelasnya komposisi PNS menurut jenis kelamin dan golongan ruang disajikan pada Tabel 1 .

Sesuai dengan teknik pemilihan sampel, secara proporsional 200 kuesioner diedarkan kepada para pegawai di lingkungan pemerintah daerah Kabupaten Serdang Bedagai, namun jawaban responden yang kembali dan layak analisis sebanyak 139 sampel. Meskipun dalam kuesioner yangdiajukan melibatkan karakteristik responden seperti jenis kelamin, usia, tingkat pendidikan, jabatan dan masa kerja, tetapi dalam pembahasannya tidak dianalisis berdasarkan kelompok-kelompok tersebut. Hal ini dilakukan untuk memperoleh hasil yang tidak ekslusif dan bersifat universal, sehingga dapat di generalisasi tanpa adanya pembatasan usia, gender dan sebagainya. Untuk memberikan gambaran umum mengenai hasil pengukuran tersebut, disajikan dalam Tabel 2. 
Tabel 1. Jumlah PNS Kabupaten Serdang Bedagai Menurut Jenis Kelamin dan Golongan Ruang

\begin{tabular}{|c|c|c|c|c|c|}
\hline \multirow{2}{*}{ No } & \multirow{2}{*}{ Pangkat } & \multirow{2}{*}{$\begin{array}{c}\text { Gol. } \\
\text { Ruang }\end{array}$} & \multicolumn{3}{|c|}{ Jenis Kelamin } \\
\hline & & & Laki-Laki & Perempuan & Jumlah \\
\hline 1 & Juru Muda & $\mathrm{I} / \mathrm{a}$ & 3 & 0 & 3 \\
\hline 2 & Juru & $\mathrm{I} / \mathrm{c}$ & 24 & 5 & 29 \\
\hline 3 & Juru Tingkat I & $\mathrm{I} / \mathrm{d}$ & 5 & 0 & 5 \\
\hline 4 & Pengatur Muda & $\mathrm{II} / \mathrm{a}$ & 305 & 223 & 528 \\
\hline 5 & Pengatur Muda Tingkat I & $\mathrm{II} / \mathrm{b}$ & 206 & 260 & 466 \\
\hline 6 & Pengatur & $\mathrm{II} / \mathrm{c}$ & 201 & 308 & 509 \\
\hline 7 & Pengatur Tingkat I & $\mathrm{II} / \mathrm{d}$ & 56 & 102 & 158 \\
\hline 8 & Penata Muda & III/a & 401 & 810 & 1.211 \\
\hline 9 & Penata Muda Tingkat I & $\mathrm{III} / \mathrm{b}$ & 250 & 423 & 673 \\
\hline 10 & Penata & $\mathrm{III} / \mathrm{c}$ & 302 & 403 & 705 \\
\hline 11 & Penata Tingkat I & $\mathrm{III} / \mathrm{d}$ & 513 & 835 & 1.348 \\
\hline 12 & Pembina & $\mathrm{IV} / \mathrm{a}$ & 711 & 1.120 & 1.831 \\
\hline 13 & Pembina Tingkat I & $\mathrm{IV} / \mathrm{b}$ & 42 & 10 & 52 \\
\hline \multirow{2}{*}{14} & Pembina Utama Muda & $\mathrm{IV} / \mathrm{c}$ & 14 & 2 & 16 \\
\hline & TOTAL & & 3.033 & 4.501 & 7.534 \\
\hline
\end{tabular}

Sumber: BKD Kab.Serdang Bedagai, 2012.

Tabel 2. Ringkasan Deskripsi Data

\begin{tabular}{|ccccccc|}
\hline Variabel & N & Minimum & Maximum & Mean & $\begin{array}{c}\text { Standard } \\
\text { Deviation }\end{array}$ & Variance \\
\hline Pembinaan: & 139 & 2.25 & 5.00 & 4.2482 & .4959 & .246 \\
X_1.1 & 139 & & & & \\
X_1.2 & 139 & 2.00 & 5.00 & 4.3129 & .5117 & .262 \\
X_1.3 & 139 & 2.00 & 5.00 & 4.0827 & .6244 & .390 \\
Motivasi kerja: & & & & & & \\
Y_1.1 & 139 & 2.30 & 5.00 & 4.0163 & .5354 & .287 \\
Y_1.2 & 139 & 2.00 & 5.00 & 4.2952 & .5030 & .253 \\
Y_1.3 & 139 & 3.00 & 5.00 & 4.2655 & .5385 & .290 \\
Produktivitas kerja: & & & & & & \\
Y_2.1 & 139 & 3.00 & 5.00 & 4.0995 & .4251 & .181 \\
Y_2.2 & 139 & 3.00 & 5.00 & 4.0432 & .4981 & .219 \\
Y_2.3 & 139 & 3.00 & 5.00 & 4.1974 & .4670 & .218 \\
Valid N (listwise) & $\mathbf{1 3 9}$ & & & & & \\
\hline Sumber: hasi alisis, 2012 & & & & & \\
\hline
\end{tabular}

Sumber: hasil analisis, 2012.

Tabel 3. Ringkasan Hasil Pengujian Validitas

\begin{tabular}{|ccccc|}
\hline Variabel & Item & Koefisien Korelasi & Sig. & Keterangan \\
\hline Pembinaan & X_1.1 & 0.576 & 0.000 & Valid \\
(X_1) & X_1.2 & 0.641 & 0.000 & Valid \\
& X_1.3 & 0.944 & 0.000 & Valid \\
Motivasi kerja & Y_1.1 & 0.742 & 0.000 & Valid \\
(Y_1) & Y_1.2 & 0.682 & 0.000 & Valid \\
& Y_1.3 & 0.644 & 0.000 & Valid \\
Produktivitas kerja & Y_2.1 & 0.842 & 0.000 & Valid \\
(Y_2) & Y_2.2 & 0.844 & 0.000 & Valid \\
& Y_2.3 & 0.788 & 0.000 & Valid \\
\hline
\end{tabular}

Sumber: hasil analisis, 2012

Tahap berikutnya adalah melakukan pengujian validitas dengan korelasi Person dan reliabilitas dengan Alpha Cronbach. Adapun ringkasan hasil pengujian disajikan pada Tabel 3 dan 4 .

Selanjutnya untuk menganalisis, mengevaluasi validitas dan kausalitas antar konstruk dari model ini digunakan software AMOS versi 16.00, yang kemudian menghasilkan indeks-indeks kesesuaian model (goodness of fit) yang disajikan pada Tabel 5.

Tabel 6 menunjukkan ringkasan hasil yang diperoleh dalam analisis dan nilai yang direkomendasikan untuk mengukur kelayakan model. 
Tabel 4. Ringkasan Hasil Pengujian Reliabilitas

\begin{tabular}{|c|c|c|c|}
\hline Variabel & Item & $\begin{array}{c}\text { Koefisien } \\
\text { Reliabilitas (Alpha) } \\
\end{array}$ & Keterangan \\
\hline $\begin{array}{l}\text { Pembinaan } \\
\quad\left(X \_1\right)\end{array}$ & $\begin{array}{l}X \_1.1 \\
X \_1.2 \\
X \_1.3\end{array}$ & 0.5441 & $\begin{array}{l}\text { Realibilitas } \\
\text { Baik }\end{array}$ \\
\hline $\begin{array}{l}\text { Motivasi kerja } \\
\quad\left(Y_{-} 1\right)\end{array}$ & $\begin{array}{l}\text { Y_1.1 } \\
\text { Y_1 } 1.2 \\
\text { Y_1.3 }\end{array}$ & 0.6147 & $\begin{array}{l}\text { Realibilitas } \\
\text { Baik }\end{array}$ \\
\hline $\begin{array}{c}\text { Produktivitas kerja } \\
\text { (Y_2) }\end{array}$ & $\begin{array}{l}\text {Y__2.1 } \\
\text { Y_2.2 } \\
\text { Y_2 } 2.3\end{array}$ & 0.7598 & $\begin{array}{l}\text { Realibilitas } \\
\text { Baik }\end{array}$ \\
\hline
\end{tabular}

Sumber: hasil analisis, 2012.

Tabel 5. Evaluasi Kriteria Indeks-Indeks Kesesuaian Model

\begin{tabular}{|lccc|}
\hline \multicolumn{1}{|c}{ Kriteria Goodness of fit index } & $\begin{array}{c}\text { Nilai Kritis } \\
\text { Cut-off Value }\end{array}$ & $\begin{array}{c}\text { Hasil } \\
\text { Model }\end{array}$ & Keterangan \\
\hline Chi-square $\left(\chi^{2}\right)$ & Diharapkan kecil & 45,049 & Baik \\
Probabilitas & $\geq 0,05$ & 0,234 & Baik \\
Derajat bebas & - & 39 & - \\
CMIN/DF & $\leq 2,00$ & 1,155 & Baik \\
GFI & $\geq 0,90$ & 0,947 & Baik \\
AGFI & $\geq 0,90$ & 0,911 & Baik \\
TLI & $\geq 0,95$ & 0,987 & Baik \\
CFI & $\geq 0,95$ & 0,991 & Baik \\
RMSEA & $\leq 0,08$ & 0,034 & Baik \\
\hline
\end{tabular}

Sumber: Hasil analisis, 2012.

Tabel 6. Hasil Uji Indikator Konstruk Variabel

\begin{tabular}{|lccccc|}
\hline \multicolumn{1}{|c}{ Arah Jalur } & Estimate & $\begin{array}{c}\text { Standardized } \\
\text { Est. }\end{array}$ & Keterangan & C.R & p-value \\
\hline X_1.1 (Disiplin kerja) $\rightarrow$ Pembinaan & 1.028 & 0.751 & Signifikan & 8.424 & 0.000 \\
X_1.2 (Karier) $\rightarrow$ Pembinaan & 1.167 & 0.832 & Signifikan & 9.281 & 0.000 \\
X_1.3 (Etika profesi) $\rightarrow$ Pembinaan & 1.315 & 0.763 & Signifikan & 8.551 & 0.000 \\
Y_1.1 (Dorongan) $\rightarrow$ Motivasi kerja & 1.000 & 0.691 & Signifikan & & \\
Y_1.2 (Harapan) $\rightarrow$ Motivasi kerja & 0.880 & 0.647 & Signifikan & 6.427 & 0.000 \\
Y_1.3 (Insentif) $\rightarrow$ Motivasi kerja & 1.023 & 0.702 & Signifikan & 6.250 & 0.000 \\
Y_2.1 (Efisiensi) $\rightarrow$ Produktivitas kerja & 1.000 & 0.897 & Signifikan & & \\
Y_2.2 (Masukan) $\rightarrow$ Produktivitas kerja & 0.936 & 0.762 & Signifikan & 8.827 & 0.000 \\
Y_2.3 (Keluaran) $\rightarrow$ Produktivitas kerja & 0.803 & 0.656 & Signifikan & 7.681 & 0.000 \\
\hline
\end{tabular}

Sumber: hasil analisis, 2012.

Seluruh kriteria telah mencapai batas nilai yang diharapkan, sehingga hasil permodelan ini dapat diterima. Dengan demikian, dapat dinyatakan bahwa pengujian ini menghasilkan konfirmasi yang baik atas konstruk serta hubungan kausalitas antar konstruk. Probabilita atau tingkat signifikansi melebihi 0,05 mengindikasikan bahwa tidak ada perbedaan signifikan antara matriks kovarians data dengan matriks kovarians yang diestimasi, sehingga model tersebut dapat diterima dan mengindikasikan model tersebut tidak berbeda seperti fakta di pemerintah daerah Kabupaten Serdang Bedagai.

Dari hasil model analisis SEM untuk melihat konsep variabel endogen dan eksogen, maka model struktural yang diperoleh dari analisis tersebut adalah:
1. Motivasi kerja $=$
0.75 (Pembinaan)

2. Produktivitas kerja $=0.12$ (Pembinaan)

3. Produktivitas kerja $=0.47$ (Motivasi kerja)

4. Produktivitas kerja $=0.75$ (Pembinaan) +0.47 (Motivasi kerja)

Hasil analisis model struktural koefisien pembangun konstruk variabel oleh masing-masing indikator dijelaskan oleh koefisien masing-masing indikator seperti Tabel 6

Pengaruh masing-masing indikator pembinaan, motivasi kerja dan produktivitas kerja adalah kuat (standardized est >0,05). Bobot ini menjelaskan bahwa pengaruh pembinaan bersumber dari pengaruh perubahan indikatornya secara merata antara 0,7510,832. Pengaruh motivasi kerja bersumber dari pengaruh perubahan indikatornya secara merata antara 0,647-0,702. Begitu pula pengaruh produktivitas kerja 
Tabel 7. Ringkasan Hasil Pengujian Hipotesis

\begin{tabular}{|c|c|c|c|}
\hline Hipotesis & $\begin{array}{l}\text { Standardized } \\
\text { Est. }\end{array}$ & p-value & Kesimpulan \\
\hline Pembinaan berpengaruh terhadap produktivitas kerja & 0.119 & 0.449 & $\begin{array}{l}\text { Tidak berpengaruh } \\
\text { signifikan }\end{array}$ \\
\hline Pembinaan berpengaruh terhadap motivasi kerja & 0.753 & 0.000 & Berpengaruh signifikan \\
\hline $\begin{array}{l}\text { Motivasi kerja berpengaruh terhadap produktivitas } \\
\text { kerja }\end{array}$ & 0.468 & 0.005 & Berpengaruh signifikan \\
\hline $\begin{array}{l}\text { Pembinaan melalui motivasi kerja berpengaruh } \\
\text { terhadap produktivitas kerja }\end{array}$ & $\begin{array}{l}0.753 \\
0.468\end{array}$ & $\begin{array}{l}0.000 \\
0.005\end{array}$ & Berpengaruh signifikan \\
\hline
\end{tabular}

Sumber: hasil analisis, 2012

bersumber dari perubahan indikatornya secara merata antara 0,656-0,897. Dengan demikian, persamaan yang terbentuk untuk masing-masing konstruk variabel adalah:

1. Pembinaan $=0.751+0,832+0,763$

2. Motivasi kerja $=0.691+0.647+0.702$

3. Produktivitas kerja $=0.897+0.762+0.656$

Tahap berikutnya adalah melakukan pengujian hipotesis nol untuk mengetahui hubungan kausalitas di antara variabel. Hasil pengujian hipotesis dapat dilihat pada Tabel 7.

Pada pengujian hipotesis satu, pengaruh positif dari pembinaan terhadap produktivitas kerja tidak dapat diterima pada taraf signifikansi 0,05. Secara umum, hal ini menjelaskan bahwa pembinaan tidak signifikan berpengaruh positif terhadap produktivitas kerja. Hal ini berarti pada kondisi disiplin kerja, karier, dan etika profesi, tidak berakibat langsung pada naiknya produktivitas kerja. Dengan demikian, hipotesis satu tentang adanya pengaruh pembinaan terhadap produktivitas kerja ini tidak dapat diterima.

Tidak diterimanya hipotesis satu penelitian ini menunjukkan gambaran bahwa model pembinaan pada pemerintah daerah Kabupaten Serdang Bedagai tidak mempunyai kontribusi dalam membentuk produktivitas kerja disana. Temuan ini tidak sejalan dengan Thoha (1993) mengatakan bahwa pembinaan merupakan suatu tindakan, proses, hasil, atau pernyataan menjadi lebih baik. Pembinaan menunjukkan adanya kemajuan, peningkatan, perubahan, evolusi atas berbagai kemungkinan, berkembang, atau peningkatan atas sesuatu. Menurut Thoha, bahwa semakin baik pembinaan yang dilakukan, maka akan semakin meningkatkan produktivitas kerja secara relatif, artinya semakin baik pembinaan yang dilakukan unsur pimpinan terhadap pegawai, maka akan semakin meningkat pula produktivitas kerjanya. Dalam observasi peneliti, tidak diterimanya hipotesis ini dapat dijelaskan pada kondisi obyektif yang ada, yaitu (1) meskipun pendekatan kepemimpinan terarah pada pembinaan, di mana peran pemimpin yang memberikan perhatian terhadap individu, mengarah pada visi dan misi pemerintah daerah, memberikan dukungan motivasi, dan menciptakan cara-cara baru dalam bekerja, namun gaya dan karakter pembinaan masa lalu dengan nuansa birokrasi dan penguasa masih ada dan melekat, sehingga tidak menstimulus motivasi pegawai untuk meningkatkan produktivitasnya; (2) seiring dengan reformasi birokrasi, setiap SKPD dan individu pegawai diberi beban target hasil kerja yang ditentukan secara kuantitatif, membuat pegawai harus mulai mampu mengatur dirinya sendiri dalam pemenuhan target SKPD, sehingga unsur pembinaan tidak terlalu berperan dalam proses tersebut, kalaupun ada hanya sebatas fasilitasi dan konsultasi saja.

Namun demikian, pembinaan di lingkungan pemerintah daerah Kabupaten Serdang Bedagai harus tetap berjalan, hal ini tidak terlepas dari peran pemimpin (Bupati) yang kemudian membawa corak dan warna baru dalam model pembinaan yang lebih demokratis, inovatif dan visioner. Warna pembinaan tersebut juga sangat mempengaruhi pola kepemimpinan di lingkungan pemerintah daerah Kabupaten Serdang Bedagai yang dituntut untuk lebih mampu memberdayakan dan meningkatkan motivasi para pegawainya serta mampu mempengaruhi cara berpikir baru (new mindset) para pegawainya, sehingga para pegawai pemda tersebut mampu bekerja dengan penuh semangat, penuh tanggungjawab, kreatif dan visioner serta peduli pada kualitas hasil pekerjaannya. Pola pembinaan yang diusung oleh Bupati yang berasal dari birokrasi murni tersebut sungguh-sungguh dapat mentransformasi pegawai dengan mendorong mereka melihat tujuan yang lebih tinggi dan mendorong pencapaian produktivitas kerja yang lebih baik.

Pada pengujian hipotesis dua, pengaruh positif dari pembinaan terhadap motivasi kerja ini dapat diterima pada taraf signifikansi 0,05. Secara umum, hal ini menjelaskan bahwa semakin tinggi nilai motivasi kerja disebabkan oleh semakin tingginya pembinaan yang terjadi. Koefisien regresi dalam bentuk baku (standardized beta) pada jalur ini adalah sebesar 0,753 (positif) yang berarti setiap perubahan variabel pembinaan $75,3 \%$ secara signifikan berpengaruh terhadap perubahan motivasi kerja dengan arah yang sama. Dengan demikian, dapat dinyatakan bahwa hipotesis dua tentang adanya pengaruh pembinaan terhadap motivasi kerja dapat diterima.

Diterimanya hipotesis dua konsisten dengan hasil penelitian Tim Penelitian Badan Kepegawaian Negara (2004) bahwa pembinaan mempunyai 
pengaruh dominan dalam membentuk motivasi kerja menunjukkan bahwa semakin besar penerapan pembinaan ini mempunyai peranan yang semakin besar dalam membentuk motivasi kerja. Hal yang sama dikemukakan oleh Rumanti (2002) bahwa pembinaan dalam hal etika profesi menjiwai pegawai dalam menjalankan tugasnya, sehingga mampu menyelesaikan dengan seksama, etos kerja tinggi dan penuh tanggung jawab, sehingga memperoleh hasil yang memuaskan

Dalam tatanan operasional terlihat bahwa dengan pembinaan yang diterapkan oleh Bupati dari birokrat murni, mampu mendorong semangat dan antusiasme para pegawai untuk meningkatkan motivasi kerja dalam rangka mewujudkan misinya untuk melayani masyarakat. Dengan posisi dan perannya, Bupati secara langsung terlibat dalam melahirkan, mengawal dan mengembangkan motivasi kerja birokrasi yang lebih dinamis sesuai kebutuhan terhadap pelayanan masyarakat. Hal ini nampak pada reorientasi pada value pada visi pemerintah daerah yang disampaikan kepada stakeholders-nya di Pusat. Perubahan cara pandang pemimpin (Bupati) dan pimpinan SKPD mampu mendorong terciptanya tata kelola pemerintahan (good governance) yang baik dengan berlandaskan pada prinsip-prinsip manajemen modern dan berorientasi pada pelayanan optimal kepada masyarakat. Hal itu dapat dipenuhi oleh Bupati dengan menanamkan dan memperkuat aspek-aspek motivasi kerja yang ada. Peran itu pula yang selama tiga tahun ini dilakukan oleh pembinaan di lingkungan pemerintah daerah Kabupaten Serdang Bedagai, sehingga mampu memberikan inspirasi bagi para pegawainya untuk mengadopsi goals dan values secara konsisten dengan visi yang dimiliki Bupati-nya.

Pada pengujian hipotesis tiga, pengaruh positif dari motivasi kerja terhadap produktivitas kerja ini dapat diterima pada taraf signifikansi 0,05. Secara umum, hal ini menjelaskan bahwa semakin tinggi nilai motivasi kerja mengakibatkan semakin tingginya produktivitas kerja. Koefisien regresi dalam bentuk baku (standardized beta) pada jalur ini adalah sebesar 0,468 (positif) yang berarti setiap perubahan produktivitas kerja $46,8 \%$ secara signifikan dipengaruhi oleh perubahan motivasi kerja. Dengan demikian, dapat dinyatakan bahwa hipotesis tiga tentang adanya pengaruh motivasi kerja terhadap produktivitas kerja dapat diterima.

Diterimanya hipotesis tiga ini sesuai atau konsisten dengan Simanjuntak (2000), yang menyatakan bahwa motivasi seseorang harus diperhatikan oleh pemimpin untuk menumbuhkan motivasi bawahannya agar terdorong melakukan pekerjaan yang produktif. Dalam tatanan operasional menunjukkan bahwa dengan adanya reorientasi motivasi kerja birokrat melalui program reformasi birokrasi di daerah, membuat para pegawai di pemerintah daerah Kabupaten Serdang Bedagai bersemangat dan penuh percaya diri dalam merefleksikan values tersebut dalam perilaku dan tugasnya, sehingga mampu meningkatkan kualitas dan kinerja hasil pekerjaan. Merasakan betapa pentingnya motivasi kerja dalam meningkatkan produktivitas kerja, membuat Bupati menata khusus program motivasi kerja dalam SKPD Badan Kepegawaian Daerah.

Pengujian hipotesis empat, didasarkan dari hasil pengujian hipotesis satu dan dua yang menyimpulkan bahwa pembinaan melalui motivasi kerja berpengaruh signifikan terhadap produktivitas kerja ini pada taraf signifikansi 0,05. Diterimanya hipotesis empat menunjukkan bahwa pembinaan dengan melalui pembentukan motivasi kerja yang semakin baik mempunyai kemampuan yang baik untuk meningkatkan produktivitas kerja. Artinya bahwa semakin besar penerapan pembinaan di lingkup pemerintah daerah Kabupaten Serdang Bedagai, maka semakin baik motivasi kerjanya, dan semakin baik motivasi kerja ini, maka semakin baik pula produktivitas kerjanya. Hal yang sama dikemukakan Rusdi (1992) yang mengemukakan bahwa hubungan antara pembinaan dan efektivitas atau produktivitas kerja dimediasi oleh motivasi kerja. Juga diungkapkan bahwa motivasi kerja merupakan filter yang dilalui oleh kepemimpinan dalam mempengaruhi produktivitas kerja sekaligus kinerja pemerintah daerah Kabupaten Serdang Bedagai.

\section{Keterbatasan Penelitian}

Beberapa keterbatasan penelitian, antara lain: a) hanya membahas dua variabel yang berpengaruh terhadap produktivitas kerja, yaitu: pembinaan dan motivasi kerja; b) instrumen yang diajukan dalam penelitian sifatnya tertutup tanpa memberi kesempatan kepada responden untuk mengungkapkan alasan, kritik dan saran; c) instrumen yang digunakan berupa kuesioner berbentuk skala pengukuran tanpa dilengkapi dengan pedoman wawancara; dan d) terbatas pada satu pemerintah daerah, bukan pada semua pemerintah daerah, sehingga belum mewakili pemerintah daerah secara keseluruhan.

\section{SIMPULAN}

Produktivitas kerja di lingkungan pemerintah daerah Kabupaten Serdang Bedagai dipengaruhi oleh pembinaan dari Bupati dan Pimpinan SKDP saat ini dan juga motivasi kerja yang tetap terpelihara. Oleh karena itu, dalam rangka meningkatkan kinerja pemerintah daerah Kabupaten Serdang Bedagai, Bupati dan Pimpinan SKPD Serdang Bedagai perlu merencanakan pola pengembangan pembinaan dan motivasi pegawai, agar diperoleh produktivitas kerja yang optimal dan berkualitas, yang pada gilirannya akan meningkatkan kinerja pemerintah daerah Kabupaten Serdang Bedagai. 


\section{DAFTAR PUSTAKA}

As'ad. 2001. Istilah Motivasi. Jakarta: PT. Tiga Serangkai.

Handoko, H.T. 2001. Manajemen Personalia dan Sumber Daya Manusia. Yogyakarta: BPFE.

Minor M., 2002. Coaching and Counseling (terjemahan), PPM, Jakarta.

Robbins. 1993. Kata Kunci Motivasi (Terjemahan). Mc Graw-Hill Book Company.

Rumanti, Sr. Maria, A. 2002. Dasar-Dasar Public Relations Teori dan Praktek. Jakarta: Grasindo.

Rusdi, Ayub T. 1992. Efektivitas Pelaksanaan Peraturan Disiplin Pegawai Negeri Sipil Sebagai Salah Satu Usaha Pembinaan Pegawai Pada Daerah Khusus Ibukota Jakarta. Tesis S-2 Universitas Indonesia. Jakarta.

Sastrohadiwiryo B.S. 2003. Manajemen Tenaga Kerja Indonesia, Pendekatan Administrasi dan Operasional. Jakarta: Bumi Aksara.

Saydam G. 1997. Kamus Istilah Kepegawaian. Jakarta: Pustaka Sinar Harapan,.

Siagian S.P. 2004. Teori Motivasi dan Aplikasinya. Jakarta: Rineka Cipta.

Silalahi B. 2000. Manajemen Sumber Daya Manusia. Jakarta: STIM-LPMI.

Simanjuntak P.J. 2000. Manajemen Sumber Daya Manusia. Jakarta: Program Pascasarjana, Universitas Krisnadwipayana.

Sinungan M. 2005. Produktivitas Apa dan Bagaimana. Jakarta: Bumi Aksara.

Solimun. 2002. Structural Equation Modelling (SEM) Lisrel dan Amos. Fakultas MIPA Universitas Brawijaya.

Thoha M. 1993. Pemimpin dan Kepemimpinan. Jakarta: Raja Gravindo Persada.

Tim Penelitian Badan Kepegawaian Negara. 2004. Pengaruh Pembinaan Terhadap Perilaku Pegawai Negeri Sipil. Jakarta.

Undang-Undang Nomor 36 Tahun 2003 Pembentukan Kabupaten Samosir dan Kabupaten Serdang Bedagai 
